\title{
"Det gode budskab" \\ - om udbredelse af e-læring til Aarhus Universitet vha. frivillighedens og brugervenlighedens vej
}

\author{
Mikkel Godsk, cand.it \\ E-læringsenheden, Aarhus Universitet \\ godsk@iktlab.au.dk
}

Dorte Sidelmann Jørgensen, cand.mag.

E-læringsenheden, Aarhus Universitet

dorte@iktlab.au.dk
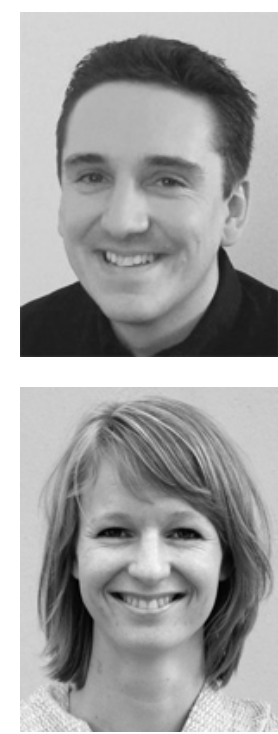

Mikkel Godsk er it-koordinator på E-læringsenheden ved Aarhus Universitet og arbejder pt. med udvikling og tilpasning af universitetets e-leringsplatform, Dokeos, til universitets behov samt integrering af platformen med de eksisterende studieadministrative- og selvbetjeningssystemer. Endvidere er Mikkel ekstern lektor på Institut for Informations- og Medievidenskab, hvor han underviser i formidling på internettet. Mikkel har som underviser førstehåndserfaring med anvendelsen af e-lceringsplatforme til blended learning samt erfaring med de tekniske aspekter i arbejdet med Dokeos og som medudvikler af e-lcringssystemet KursusWeb ${ }^{i}$.

Dorte Sidelmann Jørgensen er IKT-pæedagogisk koordinator på E-læringsenheden ved Aarhus Universitet og arbejder til daglig med administration, udvikling og support af universitetets elcringsplatform. Dorte tager sig bl.a. af vejledning af undervisere i tekniske og pæedagogiske spørgsmål vedrørende e-læring og afholder jæevnligt kurser og workshops med fokus på anvendelsen af IKT i undervisningen. Dorte har siden 2001 beskcftiget sig med såvel praktiske som teoretiske aspekter ved e-læring.

\section{Indledning}

At udbrede e-læring til en stor, universitær uddannelsesorganisation, som allerede har en velfungerende undervisningspraksis, kan være en yderst vanskelig opgave med mange organisatoriske problemstillinger. Modviljen mod forandring, herunder forventningen om den eventuelle ekstra arbejdsindsats og tidsforbrug, kan få mange undervisere til at stejle. På Aarhus Universitet har vi i valget af e-læringsplatform og udbredelsesstrategi haft disse organisatoriske faktorer i baghovedet og forsøgt at minimere deres negative effekt. Ved hjælp af et brugervenligt system med en lav indgangstærskel, brugercentreret support samt "det gode budskab” mellem kolleger, har vi i E-læringsenheden oplevet en høj grad af frivillig anvendelse af platformen. På den måde har vi været i stand til at udbrede e-læringsplatformen Dokeos til ca. $20 \%$ af universitetets potentielle brugere uden nævneværdig ”tvang”. 
Artiklen videregiver vores erfaringer og identificerer, hvilke faktorer der har betydning for at udbrede e-læring uden formaliserede anvendelseskrav.

\section{Fakta om e-læring på Aarhus Universitet}

Ligesom på andre af landets universiteter har der på Aarhus Universitet (AU) været et øget fokus på e-læringsområdet de senere år. I dag anvendes der tre forskellige e-læringsplatforme, Dokeos, FirstClass og KursusWeb ${ }^{\text {ii }}$, hvoraf de to sidstnævnte er i drift på decentralt initiativ. FirstClass anvendes af Det Humanistiske Fakultet som konference- og e-læringssystem efter en beslutning på fakultetsniveau, KursusWeb, som er et lokalt udviklet e-læringssystem, anvendes på Multimedieuddannelserne og Informationsvidenskab, mens Dokeos er et tilbud til alle universitetets fakulteter og institutter.

I sommeren 2003 blev der vedtaget en e-læringsstrategi hvis hovedformål er at sikre en vis fælles minimumsstandard på e-læringsområdet, så alle studerende og undervisere har adgang til e-læring og i princippet kan anvende de samme digitale redskaber uanset fag og organisatorisk enhed. Som led i denne plan har E-læringsenheden (en administrativ fællesenhed) fra sommeren 2004 stillet en netbaseret e-læringsplatform til rådighed for hele universitetet, der dermed kan supplere de decentralt forankrede tilbud. Den valgte platform (Dokeos) har været anvendt på universitetet i et projektforsøg siden efteråret 2002 og blev under projektperioden valgt som kursusadministrationssystem for alle kurser på Det Teologiske Fakultet. På baggrund af positive tilbagemeldinger fra både Teologi og fra andre undervisere, der har afprøvet systemet, samt forskellige undersøgelser af muligheden for at sammenkoble platformen med universitetets studieadministrative systemer, blev det vedtaget at gøre Dokeos til AU’s officielle e-læringsplatform.

E-læringsplatformen bygger på open source-teknologi og er udviklet i Belgien - først under navnet Claroline, som er udviklet i en universitær kontekst på og til universitetet i Louvainla-Neuve, og siden videreudviklet under navnet Dokeos af et firma ved samme navn med såvel offentlige som private institutioner som kunder. Platformen indeholder en række funktioner til at kommunikere med de studerende samt værktøjer til samarbejde mellem de studerende. Dokeos administreres og supporteres af universitetets E-læringsenhed, som pr. oktober 2004 består af 2,5 medarbejdere (dvs. to fuldtidsansatte teknisk-administrative medarbejdere, Dorte og Mikkel, samt en halvtidsansat daglig leder). Desuden varetager 5 studentermedhjælpere, ansat ved enhedens IKT-pædagogiske Værksted, support af de studerende, der anvender platformen. Foruden varetagelse af den daglige drift af e-læringsplatformen afholder enheden bl.a. kurser i anvendelsen af platformen og andre aspekter af IKT-anvendelse i undervisningen. I projektperioden såvel som efter den officielle lancering af e-læringsplatformen i august 2004 er antallet af brugere gradvist vokset, så der på nuværende tidspunkt (oktober 2004) er 4566 brugere $^{\mathrm{iii}}$ (undervisere, sekretærer og studerende), hvilket svarer til ca. $20 \%$ af universitets potentielle brugere - men indtil videre en lidt lavere procentdel af de potentielle, aktuelle kurser.

\section{Hjælpende faktorer}

Hvor der på flere af de danske universiteter sættes minimumskrav til anvendelsen af universiteternes e-læringssystemer ved $\mathrm{fx}$ at skrive krav om anvendelse ind i studieordningerne, har Aarhus Universitet indtil nu valgt at lade udbredelsen af systemet foregå uden formaliserede anvendelseskrav. E-læringsplatformen er udelukkende et tilbud til interesserede undervisere. Den strategi, der er valgt for udbredelsen af e-læringsplatformen på Aarhus Universitet, kan derfor karakteriseres som en "tålmodighedsstrategi", hvor underviseren selv vælger, hvornår og hvordan han/hun vil tage platformen i brug og anvende dens funktioner. Denne strategi forudsætter, at underviserne selv vil tage initiativ til at benytte platformen, og ikke mindst at de vil "reklamere" for e-læringsplatformen i deres lokale afdelinger (med mindre der fx tages 
lokale beslutninger om at anvende systemet på et helt institut eller fakultet, som det var tilfældet på Det Teologiske Fakultet ${ }^{\mathrm{iv}}$ ). Idéen er, at anvendelsen af systemet skal vokse af sig selv, og at rammerne omkring systemet, fx support og sammenkobling med de studieadministrative systemer, vokser tilsvarende. Dette vil samtidig sige, at vi, E-læringsenheden, kun i nødvendigt og begrænset omfang reklamerer for platformen for at undgå pludselige tekniske og administrative kapacitetsproblemer.

På nuværende tidspunkt synes "tålmodighedsstrategien” at virke tilfredsstillende med et stigende antal brugere hvert semester. Men siden universitetet ikke lægger pres på undervisere eller studerende mht. anvendelse af platformen, hvad gør så, at det har været relativt nemt at udbrede platformen til underviserne? Ved at granske vejen til den nuværende situation vha. de eksisterende undersøgelser (bl.a. Morten Hørning Jensens erfaringer fra Teologi (Jensen 2004) samt Dorte Sidelmann Jørgensens spørgeskemaundersøgelse blandt Clarolines underviser-brugere (Jørgensen 2004)), forskellige statistiske oplysninger om brugerne og ikke mindst E-læringsenhedens erfaringer fra den daglige drift og support, synes der at vise sig en række faktorer - både tekniske og organisatoriske/driftsmæssige - som stimulerer udbredelsen. Disse faktorer synes at omhandle følgende:

- Platformens brugervenlighed og lave "tærskel”

- Platformens tekniske tilgængelighed

- Brugercentreret support

- "Det gode budskab” mellem kolleger

- Tålmodighed i udbredelsen

- Stabil drift: høj datasikkerhed og "oppetid”

\section{Brugervenlighed og lav "tærskel"}

Erfaringer fra Det Teologiske Fakultet ved Aarhus Universitet viser, at en helt central faktor for en e-læringsplatforms udbredelse og accept samt gåpåmod blandt underviserne, er dets lave "tærskel” for anvendelse (Jensen 2004, s. 13). Den "lave tærskel” betyder, at systemet er let at komme i gang med - at det i langt de fleste tilfælde ikke er nødvendigt for en underviser at gennemlæse manualer eller deltage i kurser, før han/hun kan begynde at anvende platformen i undervisningen.

I en større sammenhæng kan den lave tærskel ses som en del af systemets brugervenlighed, og sammenholdes undervisernes opfattelse af e-læringsplatformen (fra bl.a. Jørgensens undersøgelse, 2004) med brugervenlighedsbegrebet, kan vi præcisere og klarlægge nogle af de faktorer, som kan bidrage til accepten og anvendelsen af e-læring. En meget udbredt, operationel og relativ anerkendt definition måler brugervenlighed ${ }^{\mathrm{v}}$ ved at addere faktorerne: indlceringstid, genindleringstid, effektivitet (hastighed), forståelighed (fejlrate) og subjektiv tilfredshed (Molich 2000, s. 23; og jfr. Shneiderman \& Plaisant 2005, s. 16). Især de faktorer der omhandler, hvor let systemet er at gå til (dvs. indlceringstid og forståelighed), samt underviserens subjektive oplevelse, har vist sig at være helt centrale for en problemfri udbredelse blandt underviserne (jfr. Jensen 2004, s. 13) og er derfor relevante at inspicere.

En for nylig gennemført undersøgelse blandt de godt halvanden hundrede undervisere, som på daværende tidspunkt anvendte e-læringsplatformen Claroline på Aarhus Universitet viste, at kun 19 \% havde oplevet problemer med anvendelsen. De fleste af disse problemer havde typisk karakter af enten brugerrelaterede fejl eller periodiske tekniske problemer - fx at systemet havde været nede, at underviseren havde forsøgt at uploade for store dokumenter, irritation over systemets engelske sprogbrug eller underviserens "uheldige” brug af tilbageknappen (Jørgensen 2004). 
En lidt tidligere undersøgelse af anvendelsen af Claroline på Det Teologisk Fakultet viste dog lidt flere vanskeligheder, da 63 \% svarede, at det havde været "rimeligt let” at lære at bruge Claroline, men at der var behov for kursus og/eller instruktion. Ingen mente imidlertid, at systemet var svært at anvende og krævede "stadig høj koncentration”, og hele 37 \% mente, at systemet var nemt at anvende og ikke forudsatte nogen særlig instruktion (Jensen 2004, s. 12).

Det er dog ikke specielt interessant at undersøge om underviserne synes, at systemet er let at bruge, hvis de alligevel ikke anvender det, men dette synes ikke at være tilfældet. Jørgensens undersøgelse viste, at $59 \%$ af de adspurgte undervisere anvendte Claroline én til flere gange om ugen og for Teologis vedkommende anvendte hele 68 \% platformen "ofte” eller "hver gang” i forbindelse med undervisningen. En indikation af, at de undervisere som bliver bekendte med platformen tager den til sig.

Sammenfattende for de to undersøgelser kan det bl.a. udledes, at Claroline er lettilgængeligt/har en lav tærskel, og at brugerne generelt er tilfredse med platformen ud fra deres adfærd at bedømme. I forhold til brugervenlighedsbegrebet er det altså særligt vigtigt, at faktorerne forståelighed, indlæringstid/let at lære samt subjektiv tilfredshed er opfyldt.

\section{Teknisk tilgængelighed}

Tærsklen for lettilgængelig anvendelse udgøres ikke af brugervenlighed alene. Ifølge Mikkels erfaringer med udbredelsen af KursusWeb på Aarhus Universitets multimedieuddannelser (jfr. bl.a. Bech et al. 2004, s. 260), Jensens erfaringer med Clarolines udbredelse på Det Teologiske Fakultet (Jensen, jfr. bl.a. s. 13) samt spredte erfaringer med Blackboards chatfunktion, kan den tekniske tærskel let blive for høj - selv for relativt it-kyndige brugere. Claroline og Dokeos er imidlertid udviklet ud fra filosofien om operativsystem- og webteknologiuafhængighed $^{\text {vi }}$ (jfr. Dokeos’ website) samt open source-filosofien (jfr. OSI 2004), hvilket i denne sammenhæng vil sige, at e-læringsplatformene hverken forudsætter særlige klientprogrammer, plug-ins, en særlig browser eller operativsystem installeret og derfor kan anvendes af en vilkårlig underviser med adgang til internettet ${ }^{\text {vii }}$. Platformens lave tekniske tcerskel (eller med andre ord: høje tekniske tilgæengelighed) har vist sig at være en stor fordel - ikke mindst i form af den sparede ekstraindsats blandt it-svage undervisere, som ellers ville være besværet med at installere og konfigurere supplerende software. Endvidere er dette en fordel for velviljen overfor systemet - det vi også kunne kalde den subjektive tilfredshed, men bestemt også en fordel for indlæringstiden og systemets effektivitet.

I forhold til de mere avancerede brugere, fx undervisere, som ønsker at anvende elæringssystemet til synkron kommunikation, online øvelser, undervisning vha. læringsobjekter, er det ikke tilstrækkeligt, at systemet er let at lære og subjektivt tilfredsstillende, det skal også have nogle bestemte og avancerede e-læringsfunktioner, som kan understøtte hans/hendes undervisning. Et "underviser-venligt" system for den avancerede underviser skal altså også rumme visse funktioner og anvendelsesmuligheder, før det i den kontekst kan betegnes som brugervenligt. Nyere definitioner/forståelser af brugervenlighedsbegrebet inkluderer da også dette aspekt i form af en utility-faktor, på dansk "anvendelsesmuligheder”, der måler, om systemet tilbyder den funktionalitet, som brugeren ønsker og/eller har behov for (Preece et al., s. 16).

Det er usikkert i hvilken grad Dokeos tilfredsstiller de mere avancerede brugeres behov og ønsker. I E-læringsenheden modtager vi af og til spørgsmål vedrørende Dokeos’ anvendelse til mere avanceret brug, fx dokumentdeling med versionering, videokonference, programdeling evt. integreret med chat, portfolio, booking af vejledningsmøder, telefonmøde m.fl., som systemet ikke umiddelbart understøtter. Men spørgsmålet er, om Dokeos i det hele taget skal understøtte alle disse anvendelser og inkludere disse funktioner? Med de muligheder de al- 
ment udbredte webteknologier giver, er det ikke muligt at have både en lav teknisk tærskel og avancerede e-læringsværktøjer til understøttelse af de førnævnte anvendelser. Avancerede værktøjer vil uundgåeligt forudsætte anvendelsen af webteknologier som Java, ActiveX, Real Media, QuickTime, Flash, Shockwave el.lign. hos brugerne eller et specieludviklet klientprogram og derfor bryde med filosofien om umiddelbar tilgængelighed og i stedet fordre, at brugeren installerer og konfigurerer ekstraordinær software. Endvidere er det meget vanskeligt at hamle op med de forskellige eksterne værktøjer, som udvikles af ressourcestærke virksomheder med netop disse forskellige anvendelser for øje - fx Messenger til chat og programdeling, Skype til internetbaseret telefonmøde, Windows Media Encoder til netbaseret videostreaming osv. Spredte erfaringer med anvendelsen af forskellige e-læringsplatformes chat- og audio/videokonferencefunktioner tyder da også på, at såvel underviserne som de studerende foretrækker velkendte (og eksterne) applikationer frem for de integrerede værktøjer.

\section{Brugervenlighed versus modstand mod forandring}

Brugervenligheden har vist sig at være en formildende faktor i forhold til den klassiske organisatoriske problemstilling: modstand mod forandring blandt de implicerede - herunder underviserne. Modstand mod forandring forklares gerne med en delvis psykologisk årsag; at den implicerede er usikker overfor fremtidigt jobindhold, er bange for at være magtesløs eller for at blive afskediget (Bakka \& Fivelsdal 1997, s. 257), men relateres også til mere personlige mål: at undgå at føle sig dum og lave fejl, at nå tilstrækkeligt meget arbejde og have det sjovt (i hvert fald ikke kede sig) (Cooper 1999, s. 156). Implementering af e-læring har næppe konsekvenser som magtesløshed og afskedigelse for ret mange undervisere, men en ren topstyret implementering med "påtvunget” anvendelse af e-læring vil ganske givet påvirke nogle underviseres mentalitet og som følge deraf resultere i en vis modstand mod forandring - i hvert fald hvis systemet ikke er lettilgængeligt og nemt kan inkorporeres i den eksisterende undervisning. Et system, som derimod er let at lære og forstå og måske endda er subjektivt tilfredsstillende, vil utvivlsom lette modstanden mod forandring og måske også blive mødt med en særlig entusiasme og frivillig anvendelse - og måske endda lade underviseren være og føle sig ekstraordinær akademisk og nyskabende. Det har på AU ikke været et mål i sig selv at stimulere en ændring i undervisningsformen, men først og fremmest at understøtte undervisernes mål - at undervise - og helst ikke resultere i krævende ekstraarbejde eller fx teknologiske barrierer. Et brugervenligt system kan minimere tærsklen, så underviseren ikke begår fejl, føler sig dum, usikker og ikke når tilstrækkeligt meget, og dermed opfatter e-læring som en ekstrabyrde.

\section{Brugercentreret support}

For at støtte anvendelsen af Dokeos på Aarhus Universitet har vi i E-læringsenheden valgt at supportere underviserne samt de studerende så meget som muligt. Begge målgrupper har mulighed for at hente hjælp både telefonisk, pr. e-mail og i online vejledninger, og for underviserne vedkommende udbydes der hvert semester et kursus i brugen af platformen samt inspirationsworkshops, hvor der er fokus på erfaringsudveksling samt pædagogiske spørgsmål. Herudover giver vi individuel tilpasset vejledning og afholder kurser efter ønske fra grupper af undervisere, fx ph.d.-studerende eller undervisere tilknyttet samme institut. Det vi især lægger vægt på i forbindelse med vejledning af undervisere, uanset om det er telefonisk eller på kurser, er at møde den enkelte underviser på dennes tekniske niveau. Det er væsentligt, at hver enkelt underviser kommer et skridt videre i deres brug af platformen, og ikke mindst at de får svar på det, de efterspørger. Det er derfor vigtigt at vide, hvor den enkelte underviser befinder sig mht. it-kompetencer og anvendelse af platformen.

Da det på nuværende tidspunkt primært er 1-2 personer, der tager sig af alle henvendelser fra underviserne, er det muligt at have et rimeligt overblik over den enkelte undervisers tekniske niveau og brug af e-læringssystemet. Det er et bevidst valg, at underviserne, som typisk hen- 
vender sig flere gange, altid skal kontakte den samme person i E-læringsenheden, mens studerende, der typisk kun har behov for at henvende sig én gang, kan hente hjælp hos en supportgruppe bestående af 5 forskellige studerende. På denne måde kan vi i højere grad følge den enkelte undervisers problemer og progression, og derved brugertilpasse supporten. Ved en større udbredelse vil det naturligvis ikke være muligt at lade alle undervisere (potentielt 2800 personer) henvende sig til én person. I den situation kunne det være en løsning at oprette en form for brugerprofil på den enkelte underviser, der indikerer den enkeltes tekniske niveau og tidligere anvendelse af platformen eller have lokalt forankret support på fx fakultetsniveau. Tilsvarende kunne man forstille sig en udbygning af den allerede eksisterende FAQ-funktion og de online vejledninger, så brugerne også selv vil kunne indhente den påkrævede hjælp.

\section{Det gode budskab mellem kolleger}

Når vi satser på, at undervisere spreder "det gode budskab” om hvor let og ligetil det er at anvende platformen i undervisningen, og ikke mindst hvilke administrative og pædagogiske muligheder det giver, håber vi på at kunne undgå problemer med manglende motivation og modstand mod den forandring, som ibrugtagningen af en e-læringsplatform kan indebære. Samtidig er det vores klare opfattelse, at hvis det er kolleger, der anbefaler kolleger at anvende e-læringsplatformen, kommer både undervisere og sekretærer hurtigere i gang, fordi de hjælper hinanden til at benytte systemet og spørger hinanden til råds ${ }^{\text {viii }}$. Evalueringen af brugen af Claroline fra juni 2004 (jfr. Jørgensen 2004) viser blandt andet, at $52 \%$ af de undervisere, der har deltaget i undersøgelsen, har hentet hjælp hos kolleger, hvis de har haft spørgsmål til brugen af platformen.

Der er desuden flere eksempler på, at en eller to underviseres brug af e-læringsplatformen medfører, at flere af et instituts undervisere vælger at anvende platformen. Velviljen overfor systemet eller den subjektive tilfredshed med platformen spredes måske på denne måde fra enkelte personer til deres kolleger. I hvert fald sikrer enkelte underviseres entusiasme at flere tager platformen i brug frivilligt og hurtigt. Vi anser derfor anbefalingen mellem kolleger, som den mest værdifulde metode til at udbrede e-læringsplatformen blandt universitetets undervisere - der er ingen tvivl om, at entusiasme smitter!

\section{Udfordringer i den videre udbredelse}

Den velvilje, entusiasme og motivation for at benytte e-læringsplatformen, som vi oplever blandt langt de fleste undervisere, skyldes i høj grad platformens design (brugervenlighed), udbredelsesstrategien og den brugercentrede support. Men selvom Aarhus Universitet indtil nu har haft succes med denne strategi, er spørgsmålet om e-læringsplatformen vil fortsætte med at brede sig af sig selv? Tålmodighedsstrategien har givetvis sine begrænsninger. Den nuværende udbredelse er primært båret af undervisere, som i forvejen har et rimeligt itkendskab, og som har overskud til at eksperimentere med nye kommunikationskanaler i forbindelse med undervisningen, og det vil næppe være muligt at få alle undervisere til at benytte e-læringsplatformen ad frivillighedens vej.

Erfaringer fra Open University of the Netherlands (OUNL) vedrørende indførelsen af et virtuelt læringsmiljø viser, at en udbredelsesstrategi, der satser på den frivillige ibrugtagen, virker i begyndelsen ved at tiltrække nogle meget motiverede og entusiastiske undervisere, men at denne gruppe af undervisere samtidig - uden at ville det - forhindrer andre undervisere i at "komme med på vognen"(Westera, 2004). Til gengæld fremgår det af erfaringerne fra OUNL, at en top-down-strategi giver problemer i form af bekymring og manglende motivation fra undervisernes side. Westeras anbefalinger er derfor, at man gradvis introducerer et nyt system gennem pilotprojekter suppleret med offentlige visioner, klare mål og incitamenter. Med forbehold for de forskelle der kan være mellem et åbent universitet i Holland og et traditionelt dansk universitet, kan disse erfaringer indikere, at vi måske blive nødt til at justere på vores 
udbredelsesstrategi på Aarhus Universitet, og den store udfordring bliver da at sikre undervisernes entusiasme og motivation på trods af krav om anvendelse.

Indtil nu har vi i E-læringsenheden kun beskæftiget os med udbredelsesstrategi i forhold til at få alle undervisere til at oprette sig i og efterfølgende benytte et e-læringssystem, men fokus bør også rettes mod at få underviserne til at anvende systemet til andet en blot distribution af materialer og beskeder til de studerende. En af de store udfordringer i fremtiden bliver således at udvide den fremherskende anvendelse af Aarhus Universitets e-læringsplatform som et administrativt redskab til også at fungere som et pædagogisk redskab. Dette kan gøres ved at få underviserne til at overveje hvorvidt/hvordan deres undervisningsforløb kan gentænkes indenfor den informationsteknologiske ramme, så e-læringsplatformen ikke kun er et supplement til, men en integreret del af, undervisningen. Interviews med undervisere fra Copenhagen Business School (CBS) viser i denne forbindelse, at én af de centrale barrierer for en mere pædagogisk anvendelse af en e-læringsplatform er manglende incitamenter for underviserne til at udvikle deres pædagogiske metoder (Heiberg, 2004).

Gennem en integration af e-læringsplatformen med universitetets studieadministrative systemer forventer vi, at underviserne får mere overskud til at beskæftige sig med de pædagogiske muligheder ved en e-læringsplatform. Denne implementering skal med tiden føre til, at undervisere og studerende med ét login kan få adgang til alle data, materialer samt redskaber, der er relevante for at planlægge, gennemføre og deltage i undervisningsaktiviteter. Det vil lette underviserne og sekretærer for det administrative arbejde med at oprette kursushjemmesider og lægge studerende ind i systemet. Samtidig vil det forhåbentligt også give underviserne tid til at arbejde med e-læringsplatformens redskaber i et pædagogisk perspektiv. Naturligvis bør vi i E-læringsenheden være katalysatorer for denne proces ved at stille gode eksempler/cases og andet inspirationsmateriale til rådighed.

\section{Erfaringer og konklusion}

Vi har på nuværende tidspunkt været i stand til at udbrede Dokeos til ca. 20 \% af universitetets potentielle brugere (undervisere, sekretærer og studerende) samt en lidt lavere procentdel kurser relativt problemfrit. Udbredelsen er delvis sket ved en fakultetsbeslutning på Det Teologiske Fakultet og ellers ad frivillighedens vej i form af "det gode budskab” mellem kolleger om et brugervenligt system. Vores erfaringer med denne form for frivillig anvendelse er, at den er påvirket af en række faktorer - bl.a. e-læringsplatformens brugervenlighed og tekniske tilgængelighed, motivationen for at anvende systemet/e-læring, brugersupporten og "påtvungetheden”, som det er muligt at påvirke fra centralt hold. Faktorerne har såvel teknisk som mere organisatorisk og driftmæssig karakter, og kan sammenfattes til følgende:

Platformen skal være:

\section{- Forståelig og let at lære}

Platformen skal helst være intuitivt og ”lige til at gå til” uden at forudsætte særlige kurser, ekstraordinær viden om internettet, CMS, LMS eller lignende.

\section{- Subjektivt tilfredsstillende}

Underviseren skal have en god oplevelse med anvendelsen og føle sig hjemme i systemet. Hvis systemet irriterer underviseren ved fx at være ulogisk, ustabilt og utiltalende, vil det højst sandsynligt medføre en stor modstand. Denne modstand kan i værste fald sprede sig til kolleger som "det dårlige budskab".

\section{- Fleksibel med gode anvendelsesmuligheder}

Dette gælder primært for den øvede underviser, som måske allerede har erfaringer med ét til flere e-læringsplatforme og ønsker at anvende det til avanceret brug, fx lyd- 
eller videokonference, chat og portfolio, og derudover ønsker at skræddersy sin kursushjemmeside.

- Teknisk tilgængelig

Platformen skal ikke kræve særlige klientprogrammer, browsere, plug-ins eller operativsystemer installeret hos dets brugere - en "almindelig” adgang til internettet skal være nok.

\section{- Stabil og sikker}

Det er vigtigt, at man kan regne med at systemet er stabilt og data ikke går tabt.

Derforuden bør der være en:

\section{- Brugercentreret support}

Da undervisere på universitetet er en meget heterogen gruppe med meget forskellige it-kompetencer, er det problematisk med en homogen support. Supporten bør tilpasses den enkelte underviser ud fra hans/hendes it-kompetencer og erfaringer med e-læring.

- Frivillighed $i$ anvendelsen

Universitetsundervisere er vant til en høj grad af autonomi og har det ofte vanskeligt med "tvang” - ikke mindst ovenfra - hvorfor man skal være påpasselig med denne tilgang. Det er bedre hvis "det gode budskab” spredes mellem kolleger eller måske kommer fra underviserens egne studerende.

Ovenstående er naturligvis ikke at betragte som en færdig opskrift på en succesfuld og fuldstændig problemfri udbredelse af e-læring til et helt universitet, men derimod en opridsning af nogle af de faktorer, som har stimuleret udbredelse af en e-læringsplatform til ca. 20 \% AU's potentielle brugere. Der kan være store forskelle fra universitet til universitet $\mathrm{i}$, hvordan denne fremgangsmåde vil virke, og ikke mindst hvad mulighederne er for at sprede et "godt budskab”. Problemet vedr. modstand mod forandring synes derimod at være aktuelle for langt de fleste organisationer, som skal indføre ny informationsteknologi, så mon ikke én til flere af de nævnte faktorer kan have en mere almengyldig relevans?

På trods af den indtil nu problemfri udbredelse, må vi også overveje, hvor langt vi kan nå ad frivillighedens, tålmodighedens og brugervenlighedens vej. Vi forventer at den kommende integration af e-læringsplatformen og universitets selvbetjenings- og studieadministrative systemer automatisk vil give flere brugere, men det udelukker ikke, at det kan blive nødvendigt at indføre grader af frivillighed i forbindelse med den videre udbredelse. Indtil videre er vi dog ikke stødt på frivillighedens begrænsninger og vil derfor fortsætte med "det gode budskab”.

\section{Tak til}

Tak til Jens Dørup for uforbeholdne kommentarer og konstruktiv feedback på artiklens indhold.

\section{Referencer}

Bakka, Jørgen Frode \& Fivelsdal, Egil (1997). Organisationsteori. Struktur, kultur, processer. 2. udgave. Handelshøjskolens Forlag, Munksgaard.

Bech, Christian W., Bouvin, Niels Olof, Petersen, Marianne Graves \& Grønbæk, Kaj (2004).

"En åben portal til blended learning." In: Fleksibel læering og undervisning - erfaringer, konsekvenser og muligheder med ikt. Marianne Georgsen \& Jens Bennedsen (red). Aalborg Universitetsforlag. Aalborg.

Cooper, Alan (1999). The Inmates Are Running the Asylum: Why High Tech Products Drive

Us Crazy and How to Restore the Sanity. SAMS. Indianapolis.

Dokeos. Philosophy. http://www.dokeos.com/philosophy.php. 
Heiberg, Birgitte (2004). E-learning og kompetenceudvikling. Tidsskrift for Universiteternes efter- og videreuddannelse. 1. årgang. nr. 4.

Online på: http://www.unev.dk/files/birgitte_heiberg_4.pdf.

Jensen, Morten Hørning (2004). E-læring som didaktisk provokatør. Tidsskrift for Universiteternes efter- og videreuddannelse. 1. årgang. nr. 2.

Online på: http://www.unev.dk/files/morten_horning_2.pdf.

Jørgensen, Dorte Sidelmann (2004). Evaluering af E-læeringsplatformen Claroline. Upubliceret. Aarhus Universitet.

LearningNet, It-vest (2004). http://www.learningnet.dk/L\%E6ringsplatforme/KursusWeb/.

Molich, Rolf (2000). Brugervenligt webdesign. Ingeniøren|bøger. København.

OSI (Open Source Initiative) (2004). http://www.opensource.org/docs/definition.php.

Preece, Jennifer, Rogers, Yvonne \& Sharp, Helen (2002). Interaction Design. Beyond Human-Computer Interaction. John Wiley \& Sons, Inc. New York.

Shneiderman, Ben \& Plaisant, Catherine (2005). Designing the User Interface. Strategies for Effective Human-Computer Interaction. 4th edition. Addison Wesley. Boston.

Westera, Wim (2004). "Implementing integrated e-learning: lessons learnt from the OUNL case.” In: Integrated e-learning. Eds. Jochems, Wim, Jeroen van Merriënboer \& Rob Koper. RoutledgeFalmer. London.

\footnotetext{
${ }^{\mathrm{i}}$ Læs mere om KursusWeb på LearningNets website: http://www.learningnet.dk/L\%E6ringsplatforme/KursusWeb/

ii KursusWeb blev i sommeren 2004 total redesignet og hedder nu "Studieportalen”.

iii Med forbehold for brugere med flere logins samt "forældede” logins skønner vi, at antallet af aktive brugere er ca. 4000

iv På det Teologiske Fakultet på AU er det trods fakultetsbeslutningen fortsat underviserens eget valg om han/hun vil benytte platformen. Fakultetet opfordrer underviserne til at benytte systemet og sørger for at rammerne er på plads, dvs. opretter kursushjemmesider for alle kurser og informerer de studerende om at de skal tilmelde sig kurserne på platformen. På denne måde har man på Teologi opnået at ca. 90 \% af underviserne på det ene af fakultetets to institutter benytter platformen, og det andet institut er ligeledes godt på vej.

" Den mere korrekte betegnelse ville nok være ”brugbarhed”, eftersom definitionen relaterer sig til en oversættelse af "usability"-begrebet hentet i engelsk litteratur.

vi Så systemet ikke kræver et bestemt styresystem, fx Windows, Macintosh, Linux mv., eller bestemte plug-ins til webbrowseren, fx QuickTime, Java, Flash mv.

vii I hvert fald i princippet. Forskellige kompatibilitetstests har dog vist, at Dokeos ikke fungerer på alle browsere. Der er bl.a. problemer på Netscape 6 og Internet Explorer 5.1 på Macs OsX.

viii Hertil skal også pointeres, at underviserne selv kan oprette deres profil og kursushjemmeside uden nødvendigvis at skulle konsultere e-læringsenheden.
} 